\title{
Optimization of photocatalytic fuel cells (PFCs) in the treatment of diluted palm oil mill effluent (POME)
}

\author{
Nur Syahidda Ani Moksin ${ }^{\mathrm{a}}$, Yong Por Ong ${ }^{\mathrm{b}}$, Li-Ngee Ho ${ }^{\mathrm{b}}$, Meng Guan Tay ${ }^{\mathrm{a}, *}$ \\ ${ }^{a}$ Faculty of Resource Science and Technology, Universiti Malaysia Sarawak, 94300 Kota Samarahan, Sarawak, Malaysia \\ ${ }^{\mathrm{b}}$ Faculty of Chemical Engineering Technology, Universiti Malaysia Perlis, 02600 Arau, Perlis, Malaysia
}

\section{A R T I C L E I N F O}

\section{Keywords:}

Photocatalytic fuel cell

Advanced oxidation processes (AOPs)

Immobilized $\mathrm{ZnO} / \mathrm{Zn}$

Palm oil mill effluent (POME)

Electricity generation

\begin{abstract}
A B S T R A C T
Photocatalytic fuel cells (PFCs) are considered an advanced technology in wastewater treatment as they are able to remove organic based wastewater by using the principle of advanced oxidation processes (AOPs) and at the same time generate electricity. Despite PFCs being used to treat different types of organic based wastewater efficiently, the use of PFCs in palm oil mill effluent (POME) is still considered rare. Hence, the present research was carried out to determine the optimal conditions of contact time, $\mathrm{pH}$, initial organic concentration and light intensity in order to remove the organic matter present in diluted POME. Our PFC system was constructed by using $\mathrm{NaCl}$ as the supporting electrolyte with $\mathrm{ZnO} / \mathrm{Zn}$ as the photoanode and platinum wire as the cathode. The chemical oxygen demand (COD) removal efficiency and the amount of electricity generated was monitored in different optimization experiments using a conventional fluorescence light source. Under optimal conditions, the COD removal efficiency increased from $7 \%$ to $74 \%$, while the power density output also increased from 1.73 to $35.85 \mu \mathrm{W} / \mathrm{cm}^{2}$. The PFC was found to work optimally at $\mathrm{pH} 7$ with a light intensity of $1300 \mathrm{~lx}$ for $6 \mathrm{~h}$. Meanwhile, the scanning electron microscope (SEM) images revealed the high organic matter concentration in POME can lead to the deposition of an organic layer on the photoanode surface which subsequently reduced the COD removal efficiency to $17.4 \%$. This result has indicated that PFC is not suitable for treating the fresh POME directly from the mill, but it is more suitable for treating POME, from the last biological treatment pond.
\end{abstract}

\section{Introduction}

The palm oil industry in Malaysia is an important part of the country's economy which produces an enormous amount of waste. To produce $1 \mathrm{t}$ of crude oil, about 5.0-5.7 tonnes of water is needed which will end up as palm oil mill effluent (POME) [1]. This is concerning as POME contains extremely high levels of organic matter (i.e. 16,000-50, $000 \mathrm{mg} / \mathrm{L}$ of COD) [2,3], which can cause serious pollution to the receiving water system.

Many methods have been studied for POME treatment, which have included anaerobic digestion [4], anaerobic oxidation [5], advance oxidation processes and aerobic digestion [6], ultrafiltration membrane separation, photocatalytic treatment [7] and the photo-electro-Fenton hybrid system [8]. Among them, the photocatalytic and photo-electro-Fenton hybrid system are promising solutions as these methods are highly efficient and much quicker compared to typical biological approaches.

The photocatalytic fuel cell (PFC) is another advanced version of photocatalytic technology in wastewater treatment, using the principle of advanced oxidation processes (AOPs), while also generating electricity by harvesting the electron transfer involved in the organic matter degradation process [9-13]. In theory, upon photoexcitation, the electrons $\left(e^{-}\right)$in the valence band $(\mathrm{VB})$ at the highest occupied molecular orbital (HOMO) of the photocatalyst are excited to the conduction band (CB) at the lowest unoccupied molecular orbital (LUMO), producing positively charged holes $\left(h^{+}\right)$in the valence band [Eq. (1)] [14]. Then, as shown in in Eq. (2) and (3), the formation of $h^{+}$and $e^{-}$in the system will produce the hydroxyl radical ( $(\mathrm{OH})$, which plays a vital role in organic matter degradation [15]. Electricity is harvested in the cell via the electron transfer through the external circuit from photoanode to cathode along the degradation process. Importantly, the potential difference in between the photoanode and cathode is the driving force to the flow of electrons.

Photocatalyst $+h v \rightarrow$ Photocatalyst $\left(e^{-} \mathrm{CB}+h^{+}{ }_{\mathrm{vB}}\right)$

Photocatalyst $\left(h^{+}{ }_{\mathrm{VB}}\right)+\mathrm{H}_{2} \mathrm{O} \rightarrow$ Photocatalyst $+\mathrm{H}^{+}+{ }^{\circ} \mathrm{OH}$

\footnotetext{
* Corresponding author.

E-mail address: mgtay@unimas.my (M.G. Tay).
} 